https://doi.org/10.11646/phytotaxa.346.3.2

\title{
A new pygmy sundew, Drosera albonotata (Droseraceae), from the western Wheatbelt and an updated diagnostic key to the orange-flowered pygmy Drosera of Western Australia
}

\author{
ALASTAIR S. ROBINSON ${ }^{1, *},{\text { ADAM T. } \text { CROSS }^{2}, \text { MANFRED E. MEISTERL }^{3} \text { \& ANDREAS FLEISCHMANN }}^{4}$ \\ ${ }^{1}$ 5/38 Wells Street, Southbank, VIC 3006, Australia.E-mail: arobinson@cantab.net \\ ${ }^{2}$ Centre for Mine Site Restoration, Department of Environment and Agriculture, Building 311, Curtin University, Brand Drive, Bentley, \\ WA 6102, Australia \\ ${ }^{3}$ Heinestrasse 24-28/3/26, 1020 Vienna, Austria. \\ ${ }^{4}$ Botanische Staatssammlung München, Menzinger Strasse 67, 80638 Munich, Germany; e-mail: fleischmann@bsm.mwn.de \\ *Author for correspondence
}

\begin{abstract}
A new species of Drosera-Drosera albonotata - from the western Wheatbelt (Western Australia) is described and illustrated. The taxon, which is largely restricted to sandy clay loam soils in Wandoo woodland and shrubland, is morphologically similar to D. miniata and D. coomallo but can be distinguished by its distinct floral features and ecology. A distribution map of the new species and its allies and a revised and updated diagnostic key to the twelve recognised orange-flowered pygmy Drosera in Western Australia are provided.
\end{abstract}

Keywords: Australia, carnivorous plants, Droseraceae, Drosera section Bryastrum, non-core Caryophyllales, Taxonomy

\section{Introduction}

Drosera Linnaeus (1753: 281) (Droseraceae Salisb., non-core Caryophyllales (APG IV 2016)) is a genus of herbaceous carnivorous plants and the largest carnivorous plant genus in the world, with a cosmopolitan distribution of approximately 250 species, of which $c a$. 110 are endemic to SW Australia alone (APG IV 2016, Robinson et al. 2017, Fleischmann et al. 2018). The majority of Drosera species are hemicryptophytic perennials that produce inflorescences in the form of simple scorpioid cymes (Diels 1906, Robinson et al. 2017, Fleischmann et al. 2018). Four monophyletic subgenera are currently accepted in Drosera (Fleischmann et al. 2018), of which the Australian Drosera subgenus Ergaleium (Candolle 1824: 319) Drude (1888: 271) is the largest one and the most diverse in terms of plant form and species number (see Fleischmann et al. 2018; this is the "Australian clade" of Rivadavia et al. 2003, 2012), and which includes the pygmy, tuberous and woolly sundews.

The highest rates of endemism in Drosera occur in oligotrophic Mediterranean (seasonally arid) ecosystems (Yesson \& Culham 2006, Fleischmann et al. 2018). Rates of alpha-diversity are particularly high in the quartzitic campos rupestres montane scrublands of Brazil, the sandstone-associated fynbos of South Africa, the tropical to subtropical scrublands of northern Australia and the Kwongan scrublands of Western Australia (Lambers 2014, Robinson et al. 2017, Fleischmann et al. 2018). Drosera subgenus Ergaleium sect. Bryastrum Planchon (1848: 94) diversified in the latter region. Commonly known as pygmy sundews, this group of relatively dwarf, rosetted species is characterised by (1) greatly expanded stipules, which form a protective stipule bud in the centre of the rosette which, in most pygmies, is vital to surviving the dry summer season; and (2) the ability to reproduce asexually through the production of gemmae (bulbils formed from modified leaves; Goebel 1908), with the notable exception of D. meristocaulis, an isolated species of $D$. sect. Bryastrum in South America (Rivadavia et al. 2012). A significant proportion of pygmy Drosera also produce rapidly moving unifacial marginal glands (Poppinga et al. 2012), particularly Type I glands (mucilage producing, symmetrical glandular heads positioned on relatively fast-moving, greatly elongated marginal stalks with very broad bases; for terminology, see e.g. Poppinga et al. 2012). However, Type II glands (bisymmetrical, non-glandular, trowel-like heads flattened on the abaxial side and adaxially convex, borne on very fast-moving marginal stalks) are also documented in dozens of species (Lowrie et al. 2017). 
At least four groups of species can be distinguished in Drosera sect. Bryastrum based on morphology of gemmae, the characteristics of which are fairly stable within a given species (Lowrie 1989, 2014). However, pygmy Drosera species that are not closely related can sometimes be mistakenly grouped together based on other characteristics (e.g. flower colour), which can be misleading. The orange-flowered pygmy sundews of southwest Western Australia are one such group; eleven different species occur in this region that produce only orange-petalled blooms or, in one case, a range of petal colours that may include orange. These include D. barbigera Planchon (1848: 287), D. pulchella Lehmann (1844: 38) with various flower colours including orange, D. platystigma Lehmann (1844: 37), D. hyperostigma Marchant \& Lowrie (1992: 324), D. sewelliae Diels in Diels \& Pritzel (1904: 206), D. leucoblasta Bentham (1864: 458), D. echinoblastus Marchant \& Lowrie (1992: 322), D. callistos Marchant \& Lowrie (1992: 321), D. bindoon Lowrie (2014: 1269), D. coomallo Lowrie (2014: 1269) and D. miniata Diels in Diels \& Pritzel (1904: 206).

Two of these orange-flowered species, Drosera miniata and D. coomallo, along with $D$. walyunga Marchant \& Lowrie (1992: 328) which may have white, pink or rarely salmon coloured flowers, form a natural group based on shared characteristics that include the shape of their gemmae, which are laterally compressed with an upper dorsal bulge and large growth point; their pedicels, which are reflexed (pendulous) in fruit; and their stipules, which have serrate lateral margins. This relatedness is confirmed by phylogenetic data (A. Fleischmann, unpubl. data) as well as extensive hybridisation studies performed on plants in cultivation, which have shown that $D$. miniata and the new taxon described in the present paper can readily hybridise with $D$. walyunga (M. Meisterl, pers. observ.). The production of flowers with orange petals and a dark centre is evidently a polyphyletic character in $D$. sect. Bryastrum. For example, D. barbigera belongs in a clade that includes D. scorpioides Planchon (1848: 288) and D. silvicola Lowrie \& Carlquist (1992: 105), as evidenced from morphology and confirmed by phylogeny (Rivadavia et al. 2012).

Drosera coomallo was separated from D. miniata by Lowrie (2014) based primarily on its densely glandular inflorescence, elliptic sepals with irregularly indented margins and its obovate petals. It also occurs $c a$. $100 \mathrm{~km}$ north of all known D. miniata locations (Lowrie et al. 2017). Observations of $D$. miniata material from a variety of locations have indicated that $D$. miniata (sensu Lowrie 1989, 2014) might include an additional taxon, prompting comparative observations of wild and cultivated material, along with studies of herbarium specimens. It was found that a proportion of D. miniata records do indeed comprise plants that are distinguishable from D. miniata (sensu Diels 1904, 1906) by differences in floral characteristics and ecology, which are significant characters for taxonomic delimitation in $D$. sect. Bryastrum (Lowrie 1989, 2014; Lowrie et al. 2017). Though D. barbigera, D. callistos and D. hyperostigma have been recorded in adjacent habitats in the west of its range, populations of the taxon newly described here as Drosera albonotata are mostly isolated from other pygmy Drosera species. Moreover, its characteristics remain stable between populations (and in cultivation, as compared to D. miniata) despite being dispersed across a broad, if highly fragmented, range. The taxon is herein separated from D. miniata, its closest relative in terms of flower morphology, scape indumentum and geography.

\section{Materials \& Methods}

Plant populations of Drosera albonotata and related taxa were studied in situ in Western Australia in 2008, 2013, 2014 and 2017. Measurements were made using a Leica M125C microscope with an LAS Multifocus module (Leica Microsystems Fremont, CA, USA) and a Mitutoyo vernier caliper (Mitutoyo Corporation, Japan) and taken from field collected material (ASR and ATC) subsequently deposited at PERTH (collected under license SW017966), from herbarium specimens (ASR and AF) housed in B, M and PERTH (herbarium acronyms follow Thiers 2018+), and from cultivated plants (MEM and $\mathrm{AF}$ ) grown from material purchased from Allen Lowrie.

Petal ratios were calculated from three different width measurements, A, B and C (see Discussion) made across the petals of sample materials. Lengthwise measurements were not used as these were found to vary considerably even within individual populations of a given species. Ratios were established by dividing A by B and A by C. Twosample $t$-tests were used to test for a significant difference between the ratios of A/B and A/C. Statistical analyses were calculated using RStudio (version 1.0.153, MacOS High Sierra 10.13) to assess assumptions of normality, homogeneity of variance and statistical significance of observed morphometric values in petal shape.

All de novo georeferencing was made using a Garmin Oregon 600 GPS unit with dual GPS and GLONASS telemetry enabled. Measurements were made with a minimum of 5 averaged waypoint readings over the course of a 30-minute period, with an estimated accuracy of $+/-2 \mathrm{~m}$. 
Seeds of Drosera albonotata, D. coomallo and D. miniata were harvested from cultivated plants by MEM, air dried, mounted and arranged on adhesive tape subsequently placed onto conductive stubs. The samples were sputtercoated with gold for 50 seconds in a JEOL JFC-2300HR sputter coater (JEOL, Japan). The coated samples were scanned using a JEOL JSM-IT300 scanning electron microscope (JEOL, Japan) and imaged with a TRS Sharp:eye 2 $\times 2 \mathrm{k}$ CCD camera (Troendle, Moorenwies, Germany).

The distribution map was drawn using Adobe Illustrator CC 2017 (Mac OS) based on spatial data exported from Google Earth Pro (2017).

\section{Taxonomy}

Drosera albonotata A.S.Rob., A.T.Cross, Meisterl \& A.Fleischm., sp. nov. (Figs. 1-2)

Type:-AUSTRALIA. Western Australia: Wandoo National Park, 320 m, generally in open areas on bare to gravelly, yellow to brown sandy clay loam with a moderate to dense shrub understorey in Wandoo (Eucalyptus wandoo and E. accedens) woodland, 01 October 2017, A.T. Cross \& A.S. Robinson ACAR 001 (holotype PERTH-08935858!).

Diagnosis:-Drosera albonotata is similar to $D$. miniata from which it can be distinguished by (contrasting features in parentheses) 1) its petals, which are pandurate (broadly obcuneate-obovate to obovate-subpandurate) and bear white, basal patches on either side of the midvein that are apparent both on the adaxial and abaxial petal surfaces (basal petal patches uniformly maroon-black), with more prominent venation including secondary and tertiary branching (less prominent, mostly limited to secondary branching), 2) its anther filaments, which are black at the base graduating to maroon-purple towards the thecae (filaments entirely white), 3) its sepals, which are apically more obtuse (more ovate) and inflorescences, both of which are distally more densely glandular than those of D. miniata, 4) by its more elliptic laminae (sub-orbiculate) with an average of five Type II unifacial marginal glands (seven Type II unifacial marginal glands), the abaxial surface with a greater density of eglandular trichomes.

Description:-Perennial herb, roots fibrous, plants forming compact rosettes $(0.8-) 1.5(-2.2) \mathrm{cm}$ in diameter, appressed to soil surface but old plants sometimes forming short stems to at least $4 \mathrm{~mm}$ tall, bearing withered remains of previous seasons' growth. Active leaves at anthesis (6-)8(-18); petiole 3-7 mm long, 0.4-0.7 $\mathrm{mm}$ wide near base, gradually dilating to $0.9-1.2 \mathrm{~mm}$ near lamina with slight constriction towards junction with lamina, in section somewhat narrowly elliptic, abaxially convex, adaxial surface slightly domed along midline and subconcave on either side, up to $0.5 \mathrm{~mm}$ thick, abaxial surface with scattered glands. Lamina sub-elliptic to sub-orbicular, 2.2-4.0 mm long, 2.0-2.5 $\mathrm{mm}$ wide, adaxial surface with insect-catching glands (tentacles), distal margin producing (3-)5(-7) Type II unifacial marginal glands $c a$. 4.2-6.8 mm long, retentive glands $c a$. 1.2-3.8 mm long, shorter stalked glands within, abaxial surface with scattered eglandular trichomes $c a$. $0.2-0.4 \mathrm{~mm}$ long. Stipular bud obovoid, distally tapered, basal half bristly, 3.7-5.5 mm long, 2.5-3.2 $\mathrm{mm}$ in diameter at base; stipules $c a$. 3.1-4.2 $\mathrm{mm}$ long, $c a$. 1.1-1.4 mm wide, up to $0.9 \mathrm{~mm}$ wide at base, 3-lobed; distal $1 / 2$ to $1 / 4$ of central lobe divided into 2 laciniae, each lacinia with slightly serrate margins; lateral lobes distinctly serrate or sometimes crenate on outer margin, inner margin entire, distal $1 / 2$ to $2 / 3$ laciniate into 2 segments, outer laciniae shorter than or equalling central lobe, innermost laciniae longer than central lobe. Gemmae \pm broadly elliptic, tapered at the base, in profile asymmetrically pyriform, ca. $1.2 \mathrm{~mm}$ long, $c a .0 .9 \mathrm{~mm}$ wide, $c a$. $0.9 \mathrm{~mm}$ thick. Inflorescences (1-)2(-3), each forming a (1-)5(-15)-flowered scorpioid cyme; scape (3.3-)4.9$7.2(-14.2) \mathrm{cm}$ tall including peduncle, terete, $0.25-0.38 \mathrm{~mm}$ in diameter, basally arcuate,; peduncle sparsely covered with very short, glandular trichomes, $0.049-0.15 \mathrm{~mm}$ long, longest and most dense towards apex of inflorescence; pedicels $1.8-4.5 \mathrm{~mm}$ long, pendulous in fruit, moderately glandular. Bracts if present narrowly lanceolate to subulate, 0.5-1.5 mm long, caducous (hence absent from most herbarium specimens). Flowers (16-)25(-28) $\mathrm{mm}$ in diameter. Sepals abaxially olive green, pink or maroon, the basal half fuscous, adaxially deep, blackish red throughout, \pm ovate to suboblong, with an obtuse apex, 2.5-3.2 $\mathrm{mm}$ long, 1.8-2.7 mm wide, margins entire, abaxial surface bearing scattered glandular hairs $c a .0 .18 \mathrm{~mm}$ long with translucent white stalk and red apical gland head, Petals $7-12 \mathrm{~mm}$ long, 4-8 $\mathrm{mm}$ wide at widest point, markedly pandurate, transition from proximal bout to centre bout of panduration often notched to form auriculae that often overlap with those of adjacent petals, adaxial surface orange with white basal patches either side of blackish-red midvein that are apparent in fresh specimens both adaxially and abaxially (fading in dried material), basal midvein very prominent, especially on abaxial surface, branching into 3 smaller veins that divide $c a$. 3 times before losing prominence, abaxial surface orange, slightly glaucous, margins and apex entire; petals imbricate 


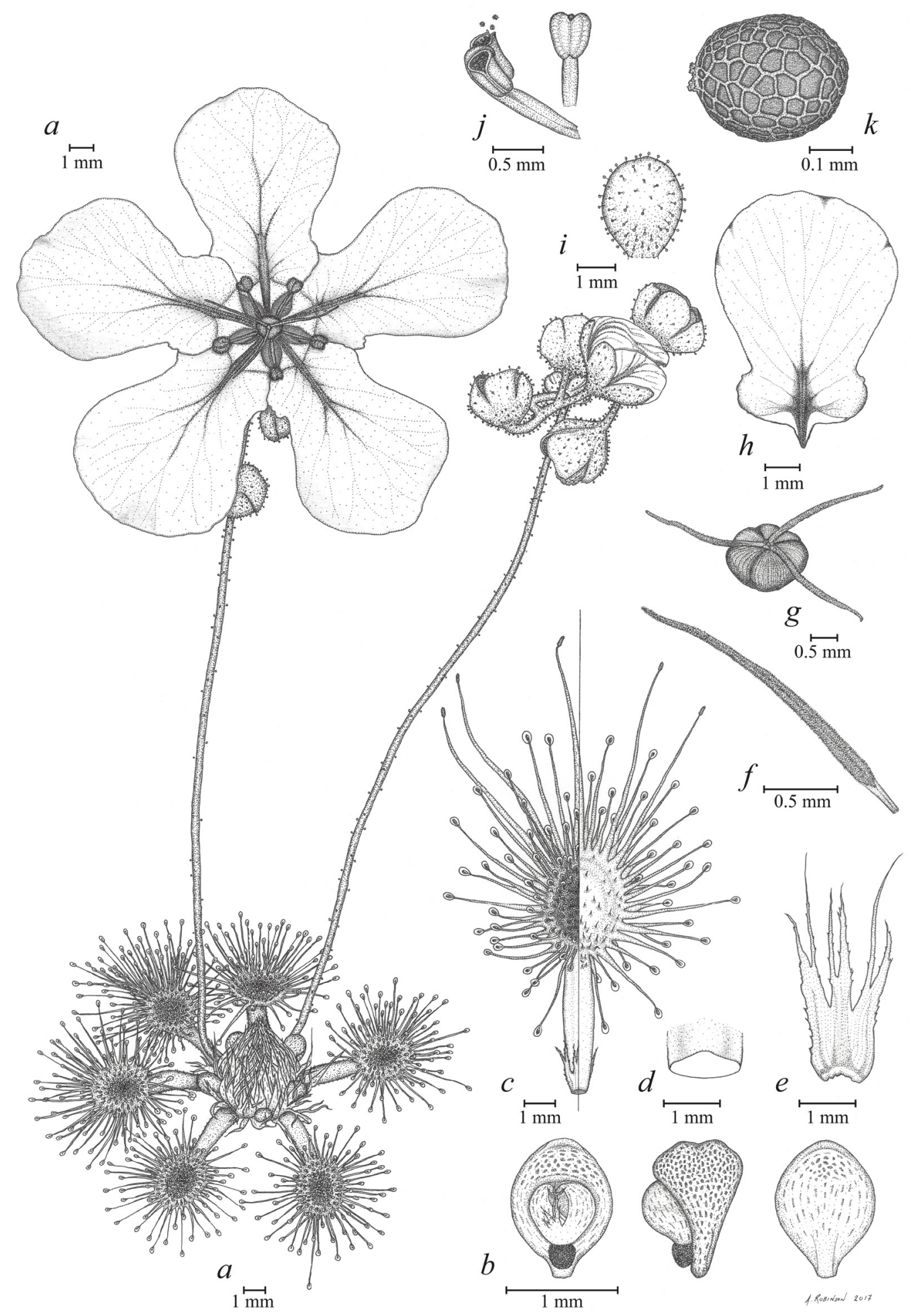

FIGURE 1. Drosera albonotata A.S.Rob., A.T.Cross, Meisterl \& A.Fleischm. a-habit of a plant with two inflorescences at anthesis. $\boldsymbol{b}$ - gemma, left adaxial surface, middle lateral view, right abaxial surface. $\boldsymbol{c}$-leaf with attached stipule as well as unifacial marginal glands, which can be relatively short-lived and not always apparent later in the season, left adaxial surface, right abaxial surface $d$-petiole cross-section. $\boldsymbol{e}$-stipule, abaxial surface. $\boldsymbol{f}$-style arm with stigma. $\boldsymbol{g}$ - gynoecium. $\boldsymbol{h}$-petal, adaxial surface. $\boldsymbol{i}$-sepal, abaxial surface. $\boldsymbol{j}$ - stamens, right sub-mature with intact anthers, left mature with extrorse longitudinal thecal dehiscence initiating at anther apex. $\boldsymbol{k}$ seed. $\boldsymbol{a}, \boldsymbol{c}, \boldsymbol{h}, \boldsymbol{j}$ from living type material prior to pressing, $\boldsymbol{b}$ from cultivated material, $\boldsymbol{d}-\boldsymbol{g}, \boldsymbol{i}$ from herbarium material, $\boldsymbol{k}$ from cultivated material visualised by SEM. Drawn by A. S. Robinson. 

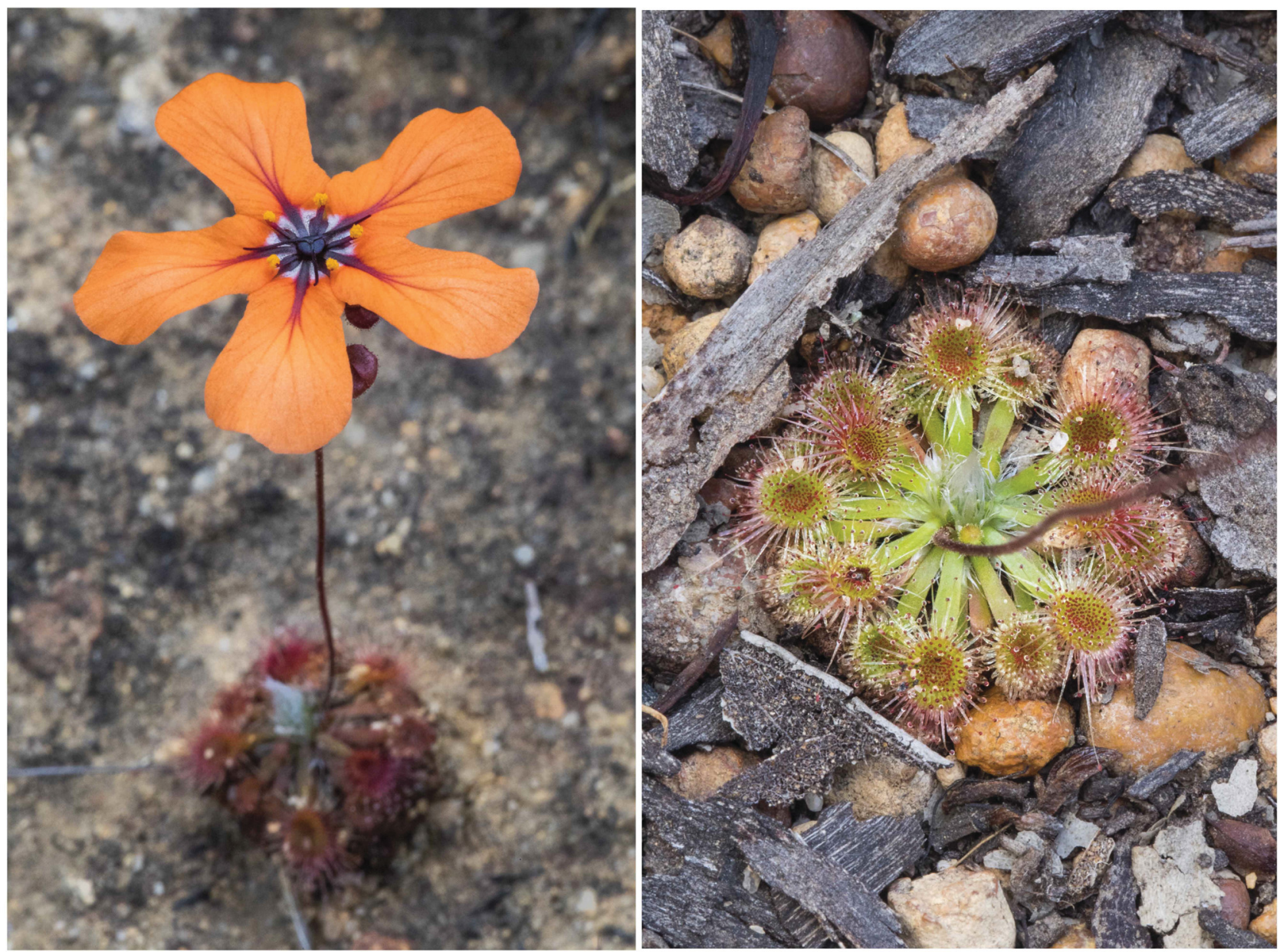

FIGURE 2. Living plants photographed in situ, showing left a flowering plant, and right a mature rosette. Photographs A.S. Robinson.

in bud. Stamens 5, 1.4-1.8 mm long; anther filaments blackish-red, sometimes apically maroon; thecae white; pollen yellow. Ovary black, broadly turbinate, apically depressed with 3 shallow grooves equidistant between styles running from apex to base, $c a$. 1.1-1.5 $\mathrm{mm}$ in diameter, to $0.7 \mathrm{~mm}$ high, surface microscopically verrucose. Styles 3 , blackishmaroon, 2.2-4.1 mm long, flagelliform, held horizontally or curving upwards towards tips, $c a$. $0.12 \mathrm{~mm}$ in diameter at base tapering towards apex, stigmatic portion microscopically papilliate. Seeds numerous, black, broadly ellipsoidal to almost hemispherical, $470-520 \mu \mathrm{m}$ long, $450-480 \mu \mathrm{m}$ in diameter, with a short funicular appendage on the terminal pole, testa isodiametrically reticulate, with anticlines thin and only shallowly raised, periclinal walls microscopically rugose.

Etymology:- the specific epithet albonotata is derived from the Latin albus (white) and notatus (marked), a reference to the two basal marks of white on each petal, the overall effect of which is a collar of white around the floral centre. This feature is wholly absent from Drosera miniata.

Phenology:- Inflorescences emerge from early September and flowering generally occurs from mid- or late September to mid-October. Flowering is coincident with diminishing rainfall associated with the approach of summer, but at this stage in the season shallow excavations show that at least some subsurface moisture persists though the surface may appear dry in the absence of recent rains. The flowers are strongly helionastic and open only on sufficiently sunny days; since flowers continue to develop in overcast conditions, the arrival of sunny weather may precipitate mass flowering.

The largest plants and flowers observed during the study period were found in the two dampest sites, while flowers and rosettes were up to a third smaller in the driest site. Edaphic causes seem unlikely to account for this difference as a few larger plants and flowers were noted in the most sheltered, humid locations amongst the smaller plants and flowers typical of the driest site studied.

Distribution and Ecology:-Drosera albonotata is restricted to the western Wheatbelt region of Western Australia. Author confirmed populations exist within the Shires of Northam, York and Quairading. Additional unconfirmed records of the taxon exist from the shires of Cunderdin, Tammin and Kellerberrin, but it was not possible to verify 
these owing to exceptionally dry conditions in the central Wheatbelt during the study period and the destruction of at least two sites for agricultural purposes. The records are tentatively supported by herbarium materials, which appear to consist of this taxon rather than $D$. miniata, though poorly pressed flowers or sterile material demand that observations of living material be made to establish certainty. A revised range of D. miniata (s.str.) is presented based on observational data and historic collections (Fig. 3), along with a proposed range for D. albonotata adapted from the range of D. miniata (s.l.) presented in Lowrie (2014).

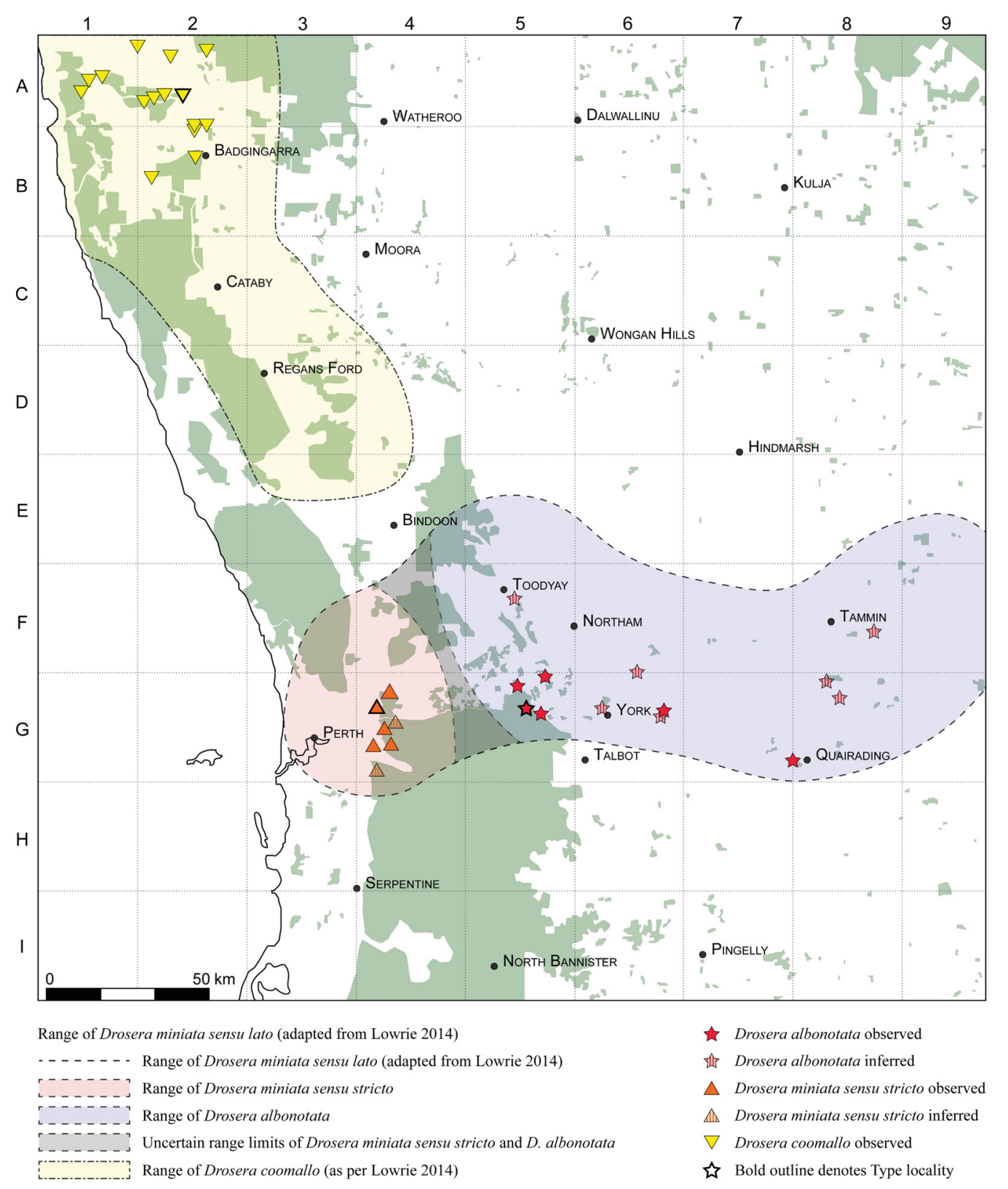

FIGURE 3. A map of the central Western Wheatbelt with the ranges of Drosera albonotata, D. coomallo and D. miniata indicated. Observed locations are those visited by the authors or their colleagues where identity of the plants present was directly confirmed. Inferred locations are those where plants thought to be of the same taxon (indicated by herbarium collections or photographs taken by cooperative members of the public) may occur but which could not be confirmed by the authors, mainly as a result of aborted or extremely early flowering during the poor flowering season that coincided with the study period (drawing by A. S. Robinson).

Drosera albonotata occurs in Wandoo (Eucalyptus wandoo Blakely and E. accedens Fitzg. (Myrtaceae)) woodland on ridges and low rises, generally on gravelly slopes and pale yellow to brown sandy clay-loam soils with a moderate to dense shrub understorey including species such as Leptospermum roei Benth. (Myrtaceae), Allocasuarina campestris (Diels) L.A.S.Johnson, A. humilis (Otto \& A.Deitr.) L.A.S.Johnson (Casuarinaceae), Banksia armata (R.Br.) A.R.Mast \& K.R.Thiele, B. sessilis (Knight) A.R.Mast \& K.R.Thiele (Proteaceae), Gastrolobium parviflorum 
(Benth.) Crisp, G. villosum Benth. (Fabaceae), Hakea lissocarpha R.Br. (Proteaceae), Hibbertia commutata Steud., H. hypericoides (DC.) Benth., H. vaginata (Benth.) F.Muell. (Dilleniaceae), Bossiaea eriocarpa Benth. (Fabaceae), Xanthorrhoea drummondii Harv. (Asphodelaceae), Trymalium ledifolium Fenzl (Rhamnaceae), Acacia pulchella R.Br. (Fabaceae), Hypocalymma angustifolium (Endl.) Schauer (Myrtaceae), Petrophile squamata R.Br. (Proteaceae), Anigozanthos humilis Lindl. (Haemodoraceae), Conostylis setigera R.Br. (Haemodoraceae), Dampiera lavandulacea Lindl. (Goodeniaceae), Melaleuca leptospermoides Schauer (Myrtaceae), Borya constricta Churchill (Boryaceae), Leschenaultia biloba Lindl. (Goodeniaceae), Pultenaea reticulata (Sm.) Benth. (Fabaceae), Daviesia decurrens Meisn. (Fabaceae), Mesomelaena tetragona (R.Br.) Benth., M. pseudostygia K.L.Wilson (Cyperaceae), Stylidium calcaratum R.Br., S. amoenum R.Br., S. ciliatum Lindl. (Stylidiaceae) and Drosera glanduligera (Lehmann 1844: 37). In five of the six field sites studied, Drosera albonotata occurred in close proximity to Gastrolobium villosum; this species may be a reasonably reliable indicator of its localisation within a broader habitat area.

Investigated populations of Drosera albonotata ranged in size from tens of plants to the low hundreds. Plants grew singly or in sparsely scattered groups mainly in open areas free of leaf litter on bare clay or surface sand, sometimes partly buried, or amongst ironstone pea-gravel in full sun to slightly shaded sites beneath shrubs amongst trees. Average monthly temperatures during the September to October flowering period are $19-22.4{ }^{\circ} \mathrm{C}$ respectively (worldbank.org 2017, Mitchell et al. 2002). All D. albonotata sites lie within the 225-450 mm Western Australian Wheatbelt May-October Rainfall Zones despite a marked western trend in isohyet movement between the 1910-1999 and 2000-2011 data periods, contrasting with D. miniata, which is recorded from the wetter 450-700 mm and >700 mm zones (Western Australian Agriculture Authority, 2014: 10; Gibson et al. 2008: 201).

At two sites, beetle pollinators apparently of the same species were observed visiting flowers of Drosera albonotata (Fig. 4) and Pultenaea reticulata. At a Baker's Hill location, 5-6 individuals were seen to circulate amongst the $c a$. 25 flowers present in one population of plants occupying an area of $2 \times 4 \mathrm{~m}$. These beetles, which were visibly dusted with pollen, were recognised as members of the beetle subfamily Melolonthinae. A tentative genus identification of Liparetrus was subsequently offered by an expert entomologist (Nicholas Porch, pers. comms.). These beetle pollinators have also been observed to visit flowers of D. glanduligera, D. hyperostigma and D. platystigma (M. Meisterl, pers. observ.).

Drosera miniata appears to occur in areas experiencing higher average rainfall than D. albonotata, and favours lateritic shrublands with shallower soils amongst comparatively open, shorter stature vegetation with dominant plants including Hakea trifurcata (Sm.) R.Br., H. undulata R.Br., Allocasuarina humilis, Beaufortia purpurea Lindl. and an understorey of Hibbertia hypericoides, Jacksonia condensata Crisp \& J.R.Wheeler, Hypocalymma angustifolium and Melaleuca scabra R.Br. The species is possibly more ruderal, favouring disturbed sites as well as the margins of paths (A. Cross and A. Robinson, pers. observ.; Keighery \& Keighery 1993: 22). Drosera miniata is also documented from Mundy Regional Park (A. Cross pers. observ.) and Kalamunda National Park (A. Robinson, pers. observ.) in shallow sands and sand with clay respectively over granite in low open heathland, with accompanying species including Acacia Mill spp., Verticordia DC. spp., and Calothamnus Labill. spp., which are typical of granite scrub.

Taxonomic notes:-Morphological similarities (see also the key below) between Drosera albonotata, D. miniata, D. coomallo and D. walyunga indicate a close relationship between these species. This is confirmed by molecular phylogenetic data, which show the four in a statistically highly-supported clade of closely related sister taxa (A. Fleischmann, unpublished data). The chromosome number of $D$. albonotata was not counted as this value is not regarded as significant by the authors since karyotype seems to be of little value to infrageneric taxonomy in $D$. sect. Bryastrum and its sister section, D. section Lasiocephala Planchon (1848: 93). Members of these two lineages, which often present odd diploid chromosome numbers (Kondo \& Lavarack 1984, Sheikh \& Kondo 1995, Sidd James in Lowrie 2014), have holocentric chromosomes (Sheikh et al. 1995, Hoshi 2002) and thus often show intraspecific aneuploid series (see e.g., Hoshi 2002).

Drosera albonotata and D. miniata are morphologically similar enough that confident identification of sterile material may pose a challenge. However, this is typical of most pygmy Drosera species in the vegetative state (Lowrie $1989,2014)$. While it is possible to distinguish between $D$. albonotata and D. miniata in the vegetative state with moderate confidence by counting the relatively short-lived Type II unifacial marginal glands if still intact (typically numbering 5 in D. albonotata and 7 in D. miniata), this characteristic is insufficient to exclude other pygmy Drosera species that may co-occur with them with certainty, though $D$. callistos and D. hyperostigma which occur in the western part of the D. albonotata range remain distinct, even when not in flower. Analysis of detached stipules and gemmae (if present) are required to increase confidence in the identification of sterile material. However, we recommend against the collection of pygmy Drosera in a non-flowering state as identification of dried sterile material is highly challenging at best. 


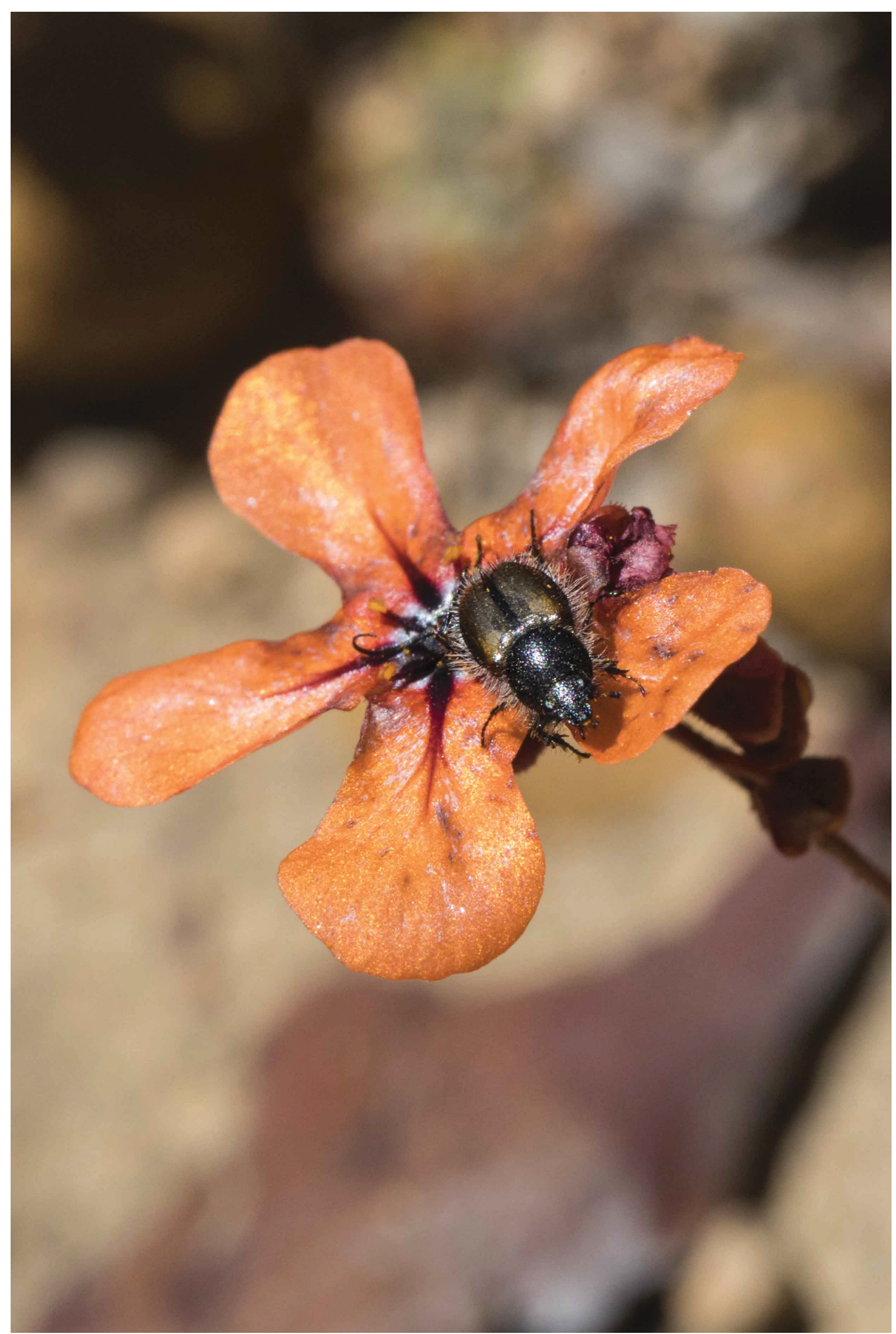

FIGURE 4. A pollinator of Drosera albonotata, identified as a Melolonthid (Scarabaeidae) possibly in the genus Liparetrus (photograph by A.S. Robinson). 

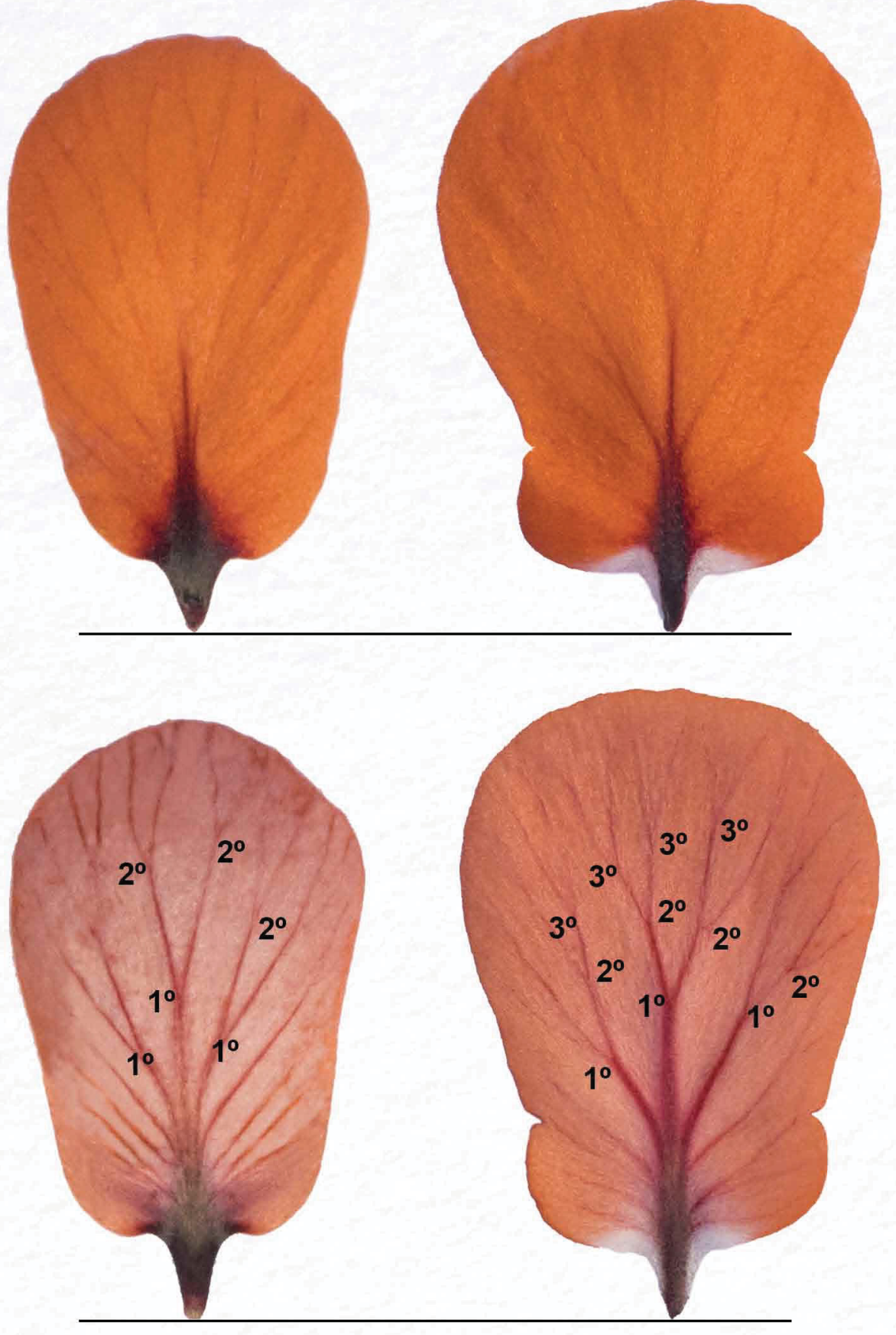

\section{$\begin{array}{ll}\text { D. miniata } & \text { D. albonotata }\end{array}$}

FIGURE 5. Comparison of the (top) adaxial and (bottom) abaxial surfaces of excised petals of Drosera miniata and D. albonotata collected at the respective type localities. Primary $\left(1^{\circ}\right)$, secondary $\left(2^{\circ}\right)$ and tertiary $\left(3^{\circ}\right)$ branching of the veins is indicated. Photographs and illustration A.S. Robinson. 


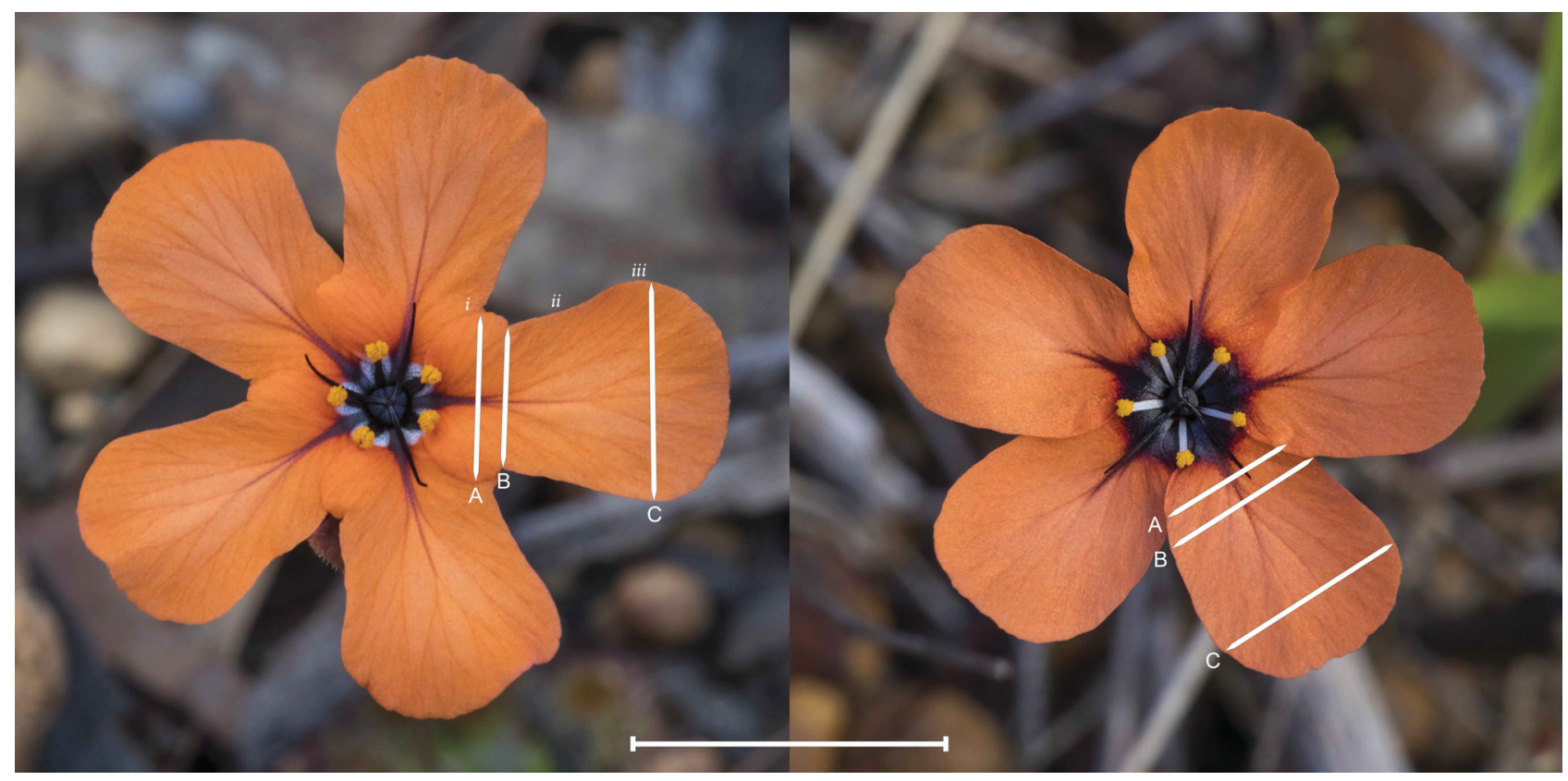

FIGURE 6. Comparison of the flowers of (left) Drosera albonotata and (right) D. miniata from their respective type localities. Scale bar $=1 \mathrm{~cm}$. Labels A, B and C indicate where comparative width measurements were made to test morphometric variation. The position of B was a fixed distance established in D. albonotata as the narrowest point of constriction of the centre bout (ii) of the pandurate shape, whilst $\mathrm{A}$ and $\mathrm{C}$ represent the widest points of the proximal $(i)$ and distal (iii) bouts respectively (photographs and illustrations by A.S. Robinson).

Flowering plants of Drosera albonotata and D. miniata are clearly differentiated by the presence of distinctive white basal petal patches in $D$. albonotata, which give rise to the impression of a ring of white about the essential whorls. Differences in petal shape, venation and size between these species are also obvious (Fig. 5) and furthermore remain discernible in dried material. The degree of panduration in the petals of $D$. albonotata varies slightly between individuals, and in some cases includes notching that gives rise to basal auriculae that may overlap (Figs. 5-6). The flowers of D. albonotata (a maximum of $2.8 \mathrm{~cm}$ in diameter) are the second largest recorded for pygmy Drosera species, after those of D. leucoblasta from the Cranbrook region (to $3.5 \mathrm{~cm}$ in diameter; Lowrie 2014; MEM \& AF pers. observ.). Although $D$. sewelliae is occasionally regarded as the largest-flowered pygmy Drosera species (Lowrie 1989: 166, Lowrie 2014: 816) given its broader, more substantial petals and its large rosette to flower size ratio, the same source coincidentally ascribes the largest flower diameter to D. leucoblasta (Lowrie 2014: 556).

The differences in venation, colouration and shape between the petals of Drosera albonotata and D. miniata are consistent. However, their petals dry to similar colours, while the characteristic white petal marks of $D$. albonotata fade somewhat in herborised material. Since subpandurate forms of D. miniata are also known, this has the potential to confound herbarium analyses. As a result, the value of morphometric data in determining identity was investigated using ratios (see Materials and Methods). The measurement points used are indicated in Fig. 6, with samples made from 22 randomly selected individuals of each species across each of the different localities studied. The $\mathrm{A} / \mathrm{C}$ ratio in petals of $D$. miniata was slightly higher $(0.70)$ than in D. albonotata $(0.65)$, which is to be expected given the shape of its petals, which tend to be slightly wider towards the apex than the base. However, a pronounced difference was observed for the A/B ratio, which more specifically measures the degree of panduration, with $\mathrm{A} / \mathrm{B}$ far higher for D. albonotata (1.14) than D. miniata (0.85). Generation of normal Q-Q plots showed that both data sets exhibited normality of distribution, with all data points lying well within the $95 \%$ confidence intervals (CI) for the normal quantiles. Application of the Levene's test of homogeneity of variance (Leven 1960) indicated that equal variance could be assumed for set $\mathrm{A} / \mathrm{C}(p>0.05$ at 0.9867$)$ but not $\mathrm{A} / \mathrm{B}(p<0.05$ at 0.002845$)$, therefore a Welch Two-sample $t$-test (Welch 1938) was used to repeat analysis of set A/B; this gave rise to the same outcome as an analysis assuming equal variance. The results of the Two-sample (A/C) and Welch Two-sample (A/B) $t$-tests found that:

- $\mathrm{A} / \mathrm{C}: t(d f=42)=-1.8531, p=0.0701,95 \% \mathrm{CI}$ for the difference in mean ratio $[D$. albonotata $0.65, D$. miniata $0.70]$, indicating no statistical significance.

- $\mathrm{A} / \mathrm{B}: t(d f=30.44)=17.406, p=<0.001,95 \% \mathrm{CI}$ for the difference in mean ratio $[D$. albonotata $1.14, D$. miniata $0.85]$, indicating statistical significance to the highest possible degree of certainty. 
These results suggest that calculation of the ratio between points A and B may be reliable indicators of species identity, with Drosera albonotata in the (1.01-)1.14(-1.24) range and D. miniata in the (0.79-)0.85(-0.90) range.

Whilst essentially irrelevant in the living state given the obvious differences in floral colour pattern, this method of analysis is valuable when analysing herbarium specimens in which the most obvious diagnostic colour characteristics of living material have faded, the white patches of Drosera albonotata being challenging to discern, though still present. Drosera walyunga (untested) may exhibit similar ratios to D. albonotata on account of its pandurate petals, however $D$. walyunga can be distinguished in dried material by its sepals, which are basally more densely glandular, and its narrower petals. In live material, it is additionally distinguished by its metallic white or pale pink petal colour, petals with less pronounced venation and a less pronounced or absent hip in the centre bout, and most notably by its narrower, white anther filaments, pale green ovary and white styles (filaments, ovary and styles black or rarely deep reddish-purple in D. albonotata).

The separation of Drosera albonotata from D. miniata does not require a recircumscription of the latter species; the type of D. miniata (Diels 4538, B!) has white anther filaments and dark styles, while the petals have no white basal markings. Diels $(1904,1906)$ noted that $D$. miniata almost always produces 1 solitary inflorescence and while this is true for the greater part of specimens examined, the authors noted a minority of otherwise typical $D$. miniata plants with 2, 3, 4 and, in one case, 5 inflorescences per plant (even on Diels' type). In contrast, D. albonotata often produces 2 scapes. Since recent treatments of D. miniata have conflated these two taxa (e.g. Lowrie 1989, 2014; Lowrie et al. 2017) care must be taken to discount characteristics previously attributed to D. miniata that are clearly derived from material representing $D$. albonotata. The main differences are those stated in the differential diagnosis and further reflected in the diagnostic key.

SEM was used to compare the seeds of the natural group comprised of Drosera albonotata, D. coomallo, D. miniata and $D$. walyunga (Fig. 7). The testa ornamentations of $D$. albonotata, D. miniata and D. walyunga are very similar. While the reticulation in D. albonotata and D. walyunga appears coarser (wells delimited by anticlines $c a$. 60-70 $\mu \mathrm{m}$ diam.) and less oblong than that of $D$. miniata (wells $c a$. 40-60 $\mu \mathrm{m}$ long $\times 35-45 \mu \mathrm{m}$ wide), the differences may not be significant between all populations. However, the slightly smaller and more rounded seeds of $D$. coomallo can apparently be told apart based on size and testa ornamentation, with the anticlines lightly raised at each junction. This may further support the separation of this species from D. miniata, as evidenced by Lowrie (2014).

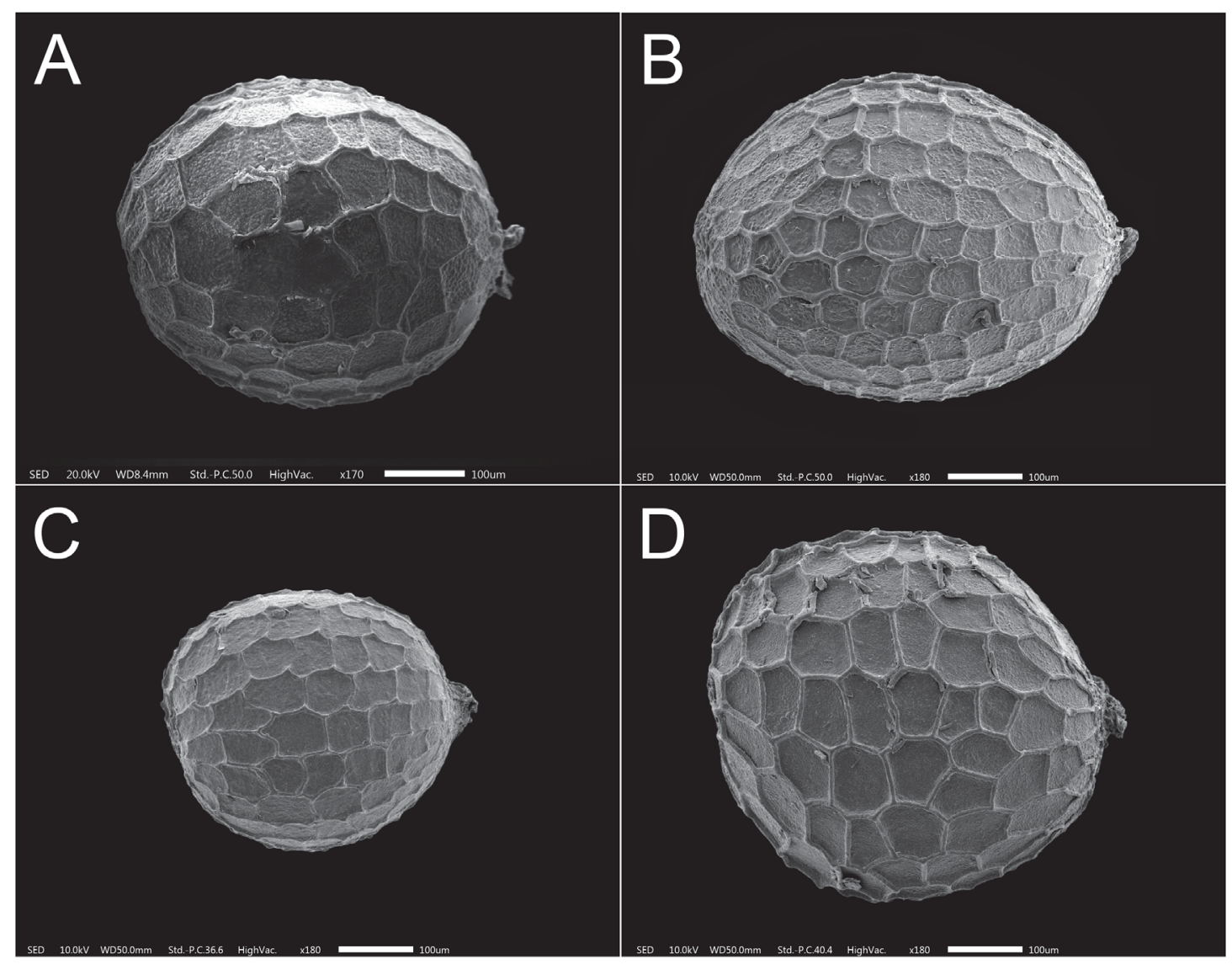

FIGURE 7. Seeds of A Drosera albonotata, B D. miniata, C D. coomallo and D D. walyunga visualised by SEM (image A by M.E. Meisterl; B, C, D by H. Halbritter). 

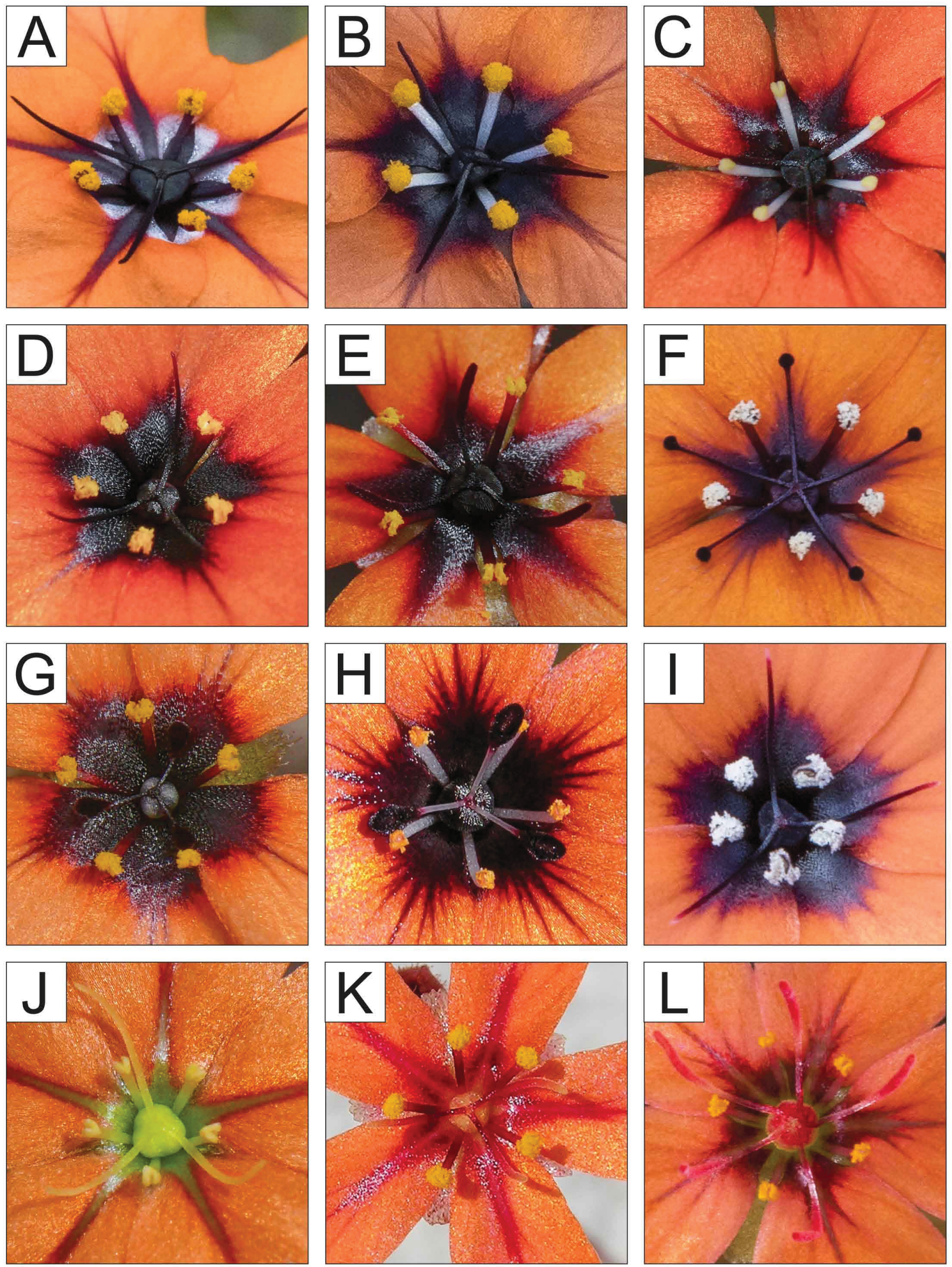

FIGURE 8. Comparison of the flowers of all twelve orange-flowered Drosera species in D. section Bryastrum. A Drosera albonotata, B D. miniata, C D. coomallo, D D. bindoon, E D. callistos, F D. sewelliae, G D. hyperostigma, H D. platystigma, I D. barbigera, J D. echinoblastus, K D. leucoblasta, L D. pulchella (orange flowered variant). Flowers not all shown at same scale (photographs C, D, E, G, H, J, K by A. Fleischmann; A, B, F, I, L by A.S. Robinson). 
Conservation status:-Direct observations of Drosera albonotata in situ satisfy the IUCN Red List Criteria of VU B2ac(iv);D2 (IUCN, 2012), i.e. the species has an AOO $<2000 \mathrm{~km}^{2}$ (known sites estimated at $2.28 \mathrm{~km}^{2}$ in total), is known from fewer than ten locations (only recorded from six relatively small populations, comprising $c a$. 25-150 individuals each), and pronounced fluctuations have been observed in the number of mature individuals at each location between seasons (A. Robinson, pers. observ.). These occur in fragmented areas that include unprotected remnant habitat spread over $87 \mathrm{~km}$ east to west (Fig. 3), surrounded by a matrix of cleared agricultural land. Thus, although additional potential habitat for this species exists in patches of remnant and secondary woodland in the region, little of this habitat is protected and populations are likely to be highly fragmented. Marked patterns of diminishing rainfall recorded for the eastern extent of the Wheatbelt (e.g. Gibson et al. 2008) may represent a long-term threat to the easternmost localities of this species. Furthermore, trends of clearing in the Avon wheatbelt region (currently at around $97 \%$ of all vegetation) have made this one of the most cleared regions in the southwest (Bradshaw 2012, Saunders 1989). This clearing has yet to cease, and ongoing habitat loss and degradation are real threats to this species, as evidenced by the conversion of at least two previous collection sites of $D$. albonotata to farm and residential land.

Diagnostic key to the orange-flowered species of Drosera sect. Bryastrum:-Taking into account the observations made during this study, a revised diagnostic key to the orange-flowered species of Drosera section Bryastrum has been devised as follows (a comparison of the flowers of all twelve species is provided in Fig. 8).

1. Upright stem-forming habit, leaves semi-erect; lamina elliptical to narrowly obovate (tentacle-bearing part of the leaf clearly longer than wide, not including tentacle length); scape with arcuate base; sepals densely covered with red glandular hairs (appearing reddish-villose); styles 3-4(-5); pollen white [the only other species with (4-)5 styles in combination with densely villose-glandular sepals and white pollen is the flat-rosetted $D$. sewelliae $]$............................................................... D. barbigera Flat-rosetted habit (aged specimens sometimes forming columns), leaves rosulate; lamina broadly elliptical, broadly obovate, circular, or broadly transversely elliptical (tentacle-bearing part of the leaf about as long as wide, not including tentacle length); scape with erect base; sepals glandular to subglabrous; styles 3-5; pollen yellow, bright orange, or white ...................................2

2. Petiole lanceolate, broadest towards the middle, up to $2 \mathrm{~mm}$ wide at greatest width; petals $\leq 6 \mathrm{~mm}$ long; styles 5 , white; anther filaments white or with white base graduating pink; plants of usually perennially wet habitats .................................D. pulchella Petiole very narrowly triangular (sometimes appearing almost linear), broadest width at the base, up to $1 \mathrm{~mm}$ wide; petals 7-10 mm long; styles 3-5, dark, reddish or yellowish-green; anther filaments dark or white; plants of generally seasonally drier habitats...3

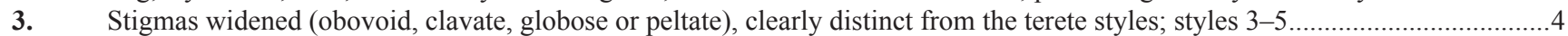
Stigmas filiform or subulate, not distinct from the styles; styles 3 (rarely 4 in exceptional, aberrant flowers)............................6

4. Stigmas peltate; style-arms white (rarely pink tinged), contrasting with the dark stigmas; anthers with white filaments; petal base dark-reddish (rarely pale red) with reddish streaks protruding into the orange part of the petals ............................ D. platystigma Stigmas obovoid-clavate or globose; styles and stigmas uniformly dark; anthers with dark filaments; petal base very dark reddishblack, surrounded by a diffuse reddish area which is clearly discernible from the orange petal colour........................................5

5. Styles 3; pollen yellow; stigmas obovoid-clavate; styles (including stigmas) $1.0-1.5 \mathrm{~mm}$ long, shorter than the anthers or equalling them in length; styles not exceeding the dark central eyespot of the flower; ovary grey; petals 6-7 mm long; sepals sparsely covered with short-stalked glands (appearing subglabrous to the naked eye in dried specimens); stipules 3-lobate, the central lobe divided into 3 laciniate segments ................................................................................................................ D. hyperostigma Styles (4-)5; pollen white (rarely yellow); stigmas globose; styles (including stigmas) 3-4 mm long, much longer than the anthers; styles clearly exceeding the dark central eyespot of the flower; ovary dark-reddish to black; petals $8-10 \mathrm{~mm}$ long; sepals densely covered with long-stalked glands (appearing hairy to the naked eye in dried specimens); stipules 3-lobate, the central lobe divided

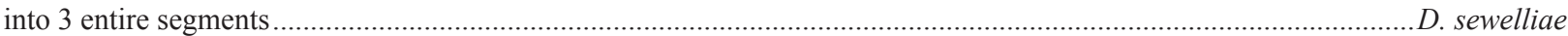

6. Petals uniformly orange (at most with reddish-maroon midvein, but never with all-encompassing blackish guide mark or white taint at the base); ovary yellowish-green, sometimes tinged dark-orange-red, rarely entirely dark (as in some cases for D. leucoblasta from the Esperance and Cranbrook regions); stigmas (i.e. the apex of each of the styles) yellowish-green, yellow or orange (even if styles dark-reddish, then stigmatic tip contrasting in colour, being much paler)................................................................... Petals bicoloured, orange with dark reddish-black guide mark or white taint at the base; ovary dark-reddish-brown to black; stigmas and styles uniformly dark-reddish-brown to black

7. Petals narrowly obovate to elliptical, not overlapping and barely touching at their bases (subjacent sepals, at least their tips, usually visible from above); stigmas subulate, with obtuse apex; anther filaments reddish to dark-red, at least in their upper part; ovary yellowish-green, but often reddish tinged, rarely entirely dark; stipule 3-lobate, lateral lobes apically 2-3-laciniate, all fringes subequal in length; all stipule fringes concavely in one plane (therefore dormant stipule bud appearing smooth in side view); pedicels erect in fruit; plants occurring south-east of Perth ................................................................................ D. leucoblasta Petals obovate, overlapping at their bases (subjacent sepals not visible from above); stigmas filiform, tapering to pointed apex; anther filaments uniformly yellowish-white; ovary yellowish-green; stipule 3-lobate, lateral lobes apically 4-5-lacinate, the lowermost lacinia longest, exceeding all other fringes; stipule fringes of lateral lobes pointing outwards (therefore dormant stipule bud appearing bristly); pedicels patent (semi-erect, held horizontal) in fruit; plants occurring north of Perth ........D. echinoblastus

8. Fruiting pedicels erect; lamina elliptical to broadly elliptical (slightly longer than wide, not including tentacle length); stipules with

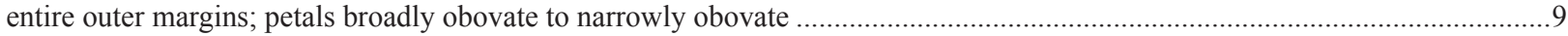
Fruiting pedicels reflexed; lamina usually suborbicular to orbicular (about as long as wide, not including tentacles' length); stipules with serrate outer margins; petals obovate, elliptical or pandurate..... 
9. Styles (including stigmas) $1.0-1.2 \mathrm{~mm}$ long, subequal to the anthers in length; stigmas subulate (and usually curved upwardly in living specimens), with obtuse apex; petals obovate, elliptical or narrowly obovate; peduncle $>5 \mathrm{~cm}$ tall ................. D. callistos Styles (including stigmas) 3.0-3.5 mm long, much exceeding the anthers in length (about twice as long); stigmas filiform, tapering to acute apex; petals broadly obovate; peduncle $\leq 5 \mathrm{~cm}$ tall ................................................................................... bindoon

10. Anther filaments white (also recognizable in dried specimens); petals obovate to slightly pandurate..........................................11 Anther filaments dull (dark maroon red to brownish-black; colour identical to that of the styles and also maintained in dried specimens); petals notably pandurate in outline (the white petal mark between dark base and orange part is clearly evident in fresh specimens and a suitable taxonomic character to distinguish it from all other orange-flowered species with a dark centre, but it is not always clearly discernible in dried materials)..... D. albonotata

11. Peduncle and sepals densely microscopically glandular; petals obovate (length:width ratio $=c a$. $3: 2$ ) to elliptical ......D. coomallo Peduncle and sepals subglabrous, sparsely glandular; petals narrowly obovate (length:width ratio $=c a .2: 1$ ) to subpandurate $\ldots \ldots . .$.

D. miniata

Finally, gemma shape is a further suitable taxonomic character by which the four species-groups of orange-flowered species of Drosera section Bryastrum can be distinguished (Lowrie 1989, 1998, 2014). However, these characters are omitted from the key as gemmae are generally not present on flowering specimens (the most frequent condition by which orange-flowered pygmy Drosera are identified as such in the field and in the herbarium; sterile specimens of most pygmy Drosera cannot be identified to species-level with certainty without at least knowledge of the exact collection locality). Gemmae-bearing individuals of the species treated here can be assigned to the following four species-groups:

a) Gemmae flat (dorsiventrally flattened), scale like, ovate to elliptical in outline; largest width below the middle; gemmae apex pointed, the very tip obtuse; growth point small, barely discernible with the naked eye $[D$. pulchella];

b) Gemmae flat (laterally compressed), asymmetrically ellipsoid; largest depth near the apex; gemmae apex obtuse; growth point small, barely discernible with the naked eye [D. platystigma];

c) Gemmae asymmetrically obovoid to turbinate, with the largest width below the middle, the largest depth near the apex; two thick lateral wings or dilatations; gemmae apex often with small apical depression and microscopically verrucose; growth point large, occupying at least $1 / 3$ of the ventral length $[D$. barbigera, $D$. bindoon, $D$. callistos, D. echinoblastus, D. hyperostigma, D. leucoblasta, D. sewelliae];

d) Gemmae laterally compressed, asymmetrically pear-shaped to ellipsoid, with largest diameter (depth) at a bulge on the upper dorsal part; without any lateral wings or dilatations; gemmae apex obtuse; growth point large, occupying at least $1 / 3$ of the ventral length $[D$. coomallo, D. miniata, D. albonotata (as well as $D$. walyunga, which is not orangeflowered)].

Additional specimens examined:-Drosera albonotata (Paratypes):-AUSTRALIA. Western Australia: Wandoo National Park, Mt. Observation Rd, 01 October 2017, A.T. Cross \& A.S. Robinson ACAR 002, (PERTH!); Northam, Baker's Hill, 02 October 2017, A.T. Cross \& A.S. Robinson ACAR 003 (PERTH!); Northam, Clackline, 02 October 2017, A.T. Cross \& A.S. Robinson ACAR 004 (PERTH!); Northam, Clackline, 07 October 2008, F. Hort \& J. Hort 3319 as D. miniata (PERTH!); York, Quairading Rd, 12 October 1977, N.G. Marchant 77/162 as D. miniata (PERTH!) [locality now turned into a wheat field; ASR pers. observ. 2017]; Quairading, Tammin National Park, 02 August 1968, R.D. Royce 8439 as D. miniata (PERTH!); York, Quellington, 28 September 1901, C. Andrews s.n. as D. miniata (PERTH!); Toodyay, Darling Range, 22 October 1983, A. Lowrie 12 as D. miniata (PERTH!); York, near Mokine Rd, 07 October 1933, W.E. Blackall 3294 as D. miniata (PERTH!) [locality now developed for residential purposes, ASR pers. observ. 2017]; Tammin, Gardner Flora Reserve, 27 Sep 1974, L. Debuhr 3816 as D. miniata (PERTH!).

Drosera coomallo:-AUSTRALIA. Western Australia: Coomallo telephone exchange, Marchagee Track, 27 September 2000, Allen Lowrie 2478 (PERTH!, holotype); Dandaragan, Hakea Reserve, 27 October 2002, F. Hort \& J. Hort 1875 as D. miniata (PERTH!); Dandaragan, S. Jurien Road East, 09 September 1999, J.W. Horn 2317 as D. miniata (PERTH!).

Drosera miniata:-AUSTRALIA. Western Australia: Swan, Swanview, in steinig kiesigem Boden in sonnigen Lagen [in stony-gravelly soil at sunny sites], 120 m, 30 September 1901, L. Diels 4538 (B!, type); Swan, Talbot Rd Res., 10 October 2009, K.R. Thiele 3867 (PERTH!); Swan, Red Hill, 10 November 1991, A. Lowrie 511 (PERTH!); Mundaring, Helena Valley, October 1992, S. James 92.10/1 (PERTH!); Mundaring, Helena Valley, 16 October 1977, J. Seabrook 365 (PERTH!); Gosnells, Ellis Brook Valley Reserve, 25 September 1999, H. Bowler 151 (PERTH!). 


\section{Acknowledgements}

The authors would like to thank the following colleagues for their invaluable assistance during the preparation of this work: Skye Coffey, Karina Knight, Julia Percy-Bower and Cheryl Parker at the Western Australia Herbarium (PERTH), Robert Vogt (Herbarium B), Fernando Rivadavia for accessibility-testing the range map for colour-blind readers, Kevin Pfeifer and Nika Pende (Department of Ecogenomics and Systems Biology), and Heidemarie Halbritter (Department of Botany and Biodiversity) and the Core Facility Cell Imaging and Ultrastructure Research (University of Vienna, Austria) for preparation of SEM images, Davide Baj (School of Science, RMIT University, Melbourne, Australia) for guiding statistical analyses, Nicholas Porch (Centre for Integrative Ecology, Deakin University, Melbourne) for beetle identification, Darren O'Brien (Perth, Australia) and Thilo Krueger (Wiesbaden, Germany) for additional field observations and location data, and Allen Lowrie (Duncraig, Western Australia) for his formidable work across the genus Drosera within Australia, which has formed the foundation upon which further regional research in Drosera can build.

\section{References}

APG (Angiosperm Phylogeny Group) IV (2016) An update of the Angiosperm Phylogeny Group classification for the orders and families of flowering plants: APG IV. Botanical Journal of the Linnean Society 181: 1-20. https://doi.org/10.1111/boj.12385

Bentham, G. (1864) Flora Australiensis, vol. 2, L. Reeve \& Co., London, 521 pp.

Bradshaw, C.J. (2012) Little left to lose: deforestation and forest degradation in Australia since European colonization. Journal of Plant Ecology 5: 109-120. https://doi.org/10.1093/jpe/rtr038

Candolle, A.P. de (1824) Prodomus systematis naturalis Regni Vegetabilis 1. Sumptibus Sociorum Treuttel et Würtz, Parisii (Paris), 746 pp.

Diels, L. (1906) Droseraceae. In: Engler, H.G.A (Ed.) Das Pflanzenreich, vol. 26 (4). W. Engelman, Weinheim, Germany, pp. 1-136.

Diels, L. \& Pritzel, E. (1904) Fragmenta Phytographiae Australiae occidentalis. Beiträge zur Kenntnis der Pflanzen Westaustraliens, ihrer Verbreitung und ihrer Lebensverhältnisse. Botanische Jahrbü̈her für Systematik, Pflanzengeschichte und Pflanzengeographie 35 (2): 55-662.

Drude, O. (1888) Droseraceae. In: Engler, H.G.A. \& Prantl, K. (Eds.) Die natürlichen Pflanzenfamilien, vol. 3 (2). W. Engelmann, Leipzig, pp. 261-272.

Fleischmann, A., Cross, A.T., Gibson, R., Gonella, P.M. \& Dixon, K.W. (2018) Systematics and evolution of Droseraceae. In: Ellison, A.M. \& Adamec, L. (eds.), Carnivorous Plants: Physiology, ecology, and evolution. Oxford University Press, pp. 45-57. https://doi.org/10.1093/oso/9780198779841.003.0004

Gibson, L., Kingwell, R. \& Doole, G. (2008) The role and value of eastern star clover in managing herbicide-resistant crop weeds: a whole-farm analysis. Agricultural Systems 98: 199-207. https://doi.org/10.1016/j.agsy.2008.07.002

Goebel, K. (1908) Morphologische und biologische Bemerkungen. 18. Brutknospenbildung bei Drosera pygmaea und einigen Monokotylen. Flora 98: 324-335.

Google Earth Pro version 7.3.0.3832 (2017) Available from: https://earth.google.com/download-earth.html (accessed 1 November 2017) IUCN (2012) IUCN Red List Categories and Criteria Version 3.1, $2^{\text {nd }}$ edition. IUCN Species Survival Commission. IUCN, Gland, Switzerland and Cambridge, UK. Available from: http://www.iucnredlist.org/static/categories_criteria_3_1 (accessed 17 December 2017)

Hoshi, Y. (2002) Chromosome studies in Drosera (Droseraceae). Proceedings of the 4th International Carnivorous Plant Conference, Tokyo, Japan: 31-38.

Keighery, G.J. \& Keighery, B. (1993) Floristics of reserves and bushland areas of the Perth Region (System 6): Parts V-IX. Wildflower Society of Western Australia Inc., Floreat, 64 pp.

Kondo, K. \& Lavarack, P.S. (1984) A cytotaxonomic study of some Australian species of Drosera L. (Droseraceae). Botanical Journal of the Linnean Society 88: 317-333. https://doi.org/10.1111/j.1095-8339.1984.tb01579.x

Lambers, H. (2014) Plant Life on the sandplains in Southwest Australia: A global biodiversity hotspot. University of Western Australia Press, Nedlands, 350 pp. 
Lehmann, J.G.C. (1844) Novarum et minus cognitarum stirpium pugillus I-X [...] 8. Typis J.A. Meissneri, Hamburgi [Hamburg], 56 pp.

Levene, H. (1960) Robust tests for equality of variances. In: Olkin, I. (Ed.) Contributions to probability and statistics: essays in honor of Harold Hotelling. Stanford University Press, Stanford, pp. 278-292.

Linnaeus, C. (1753) Species Plantarum, vol. 1. Impensis Laurentii Salvii, Holmiae [Stockholm], 572 pp.

Lowrie, A. (1989) Carnivorous plants of Australia, vol. 2. University of Western Australia Press, Perth, 202 pp.

Lowrie, A. (1998) Carnivorous plants of Australia, vol. 3. University of Western Australia Press, Perth, 288 pp.

Lowrie, A. (2014) Carnivorous plants of Australia: Magnum Opus, vols. 1-3. Redfern Natural History, Poole, Dorset, 1355 pp.

Lowrie, A. \& Carlquist, S. (1992) Eight new taxa of Drosera from Australia. Phytologia, 73: 98-116.

Lowrie, A., Robinson, A.S., Nunn, R., Rice, B., Bourke, G., Gibson, R., McPherson, S.R. \& Fleischmann, A.S. (2017) Drosera of the World 2: Oceania, Asia, Europe, North America. Redfern Natural History Productions, Dorset, 546 pp.

Marchant, N.G. \& Lowrie, A. (1992) New names and new combinations in 34 taxa of Western Australian tuberous and pygmy Drosera. Kew Bulletin 47: 315-328. https://doi.org/10.2307/4110677

Mitchell, T.D., Hulme, M. \& New, M. (2002) Climate data for political areas. Area 34: 103-112. https://doi.org/10.1111/1475-4762.00062

Planchon, J.E. (1848) Sur la famille des Droséracées. Annales des Sciences Naturelles, Botanique, Série 3 9: 79-99 + 185-206 + 285309.

Poppinga, S., Hartmeyer, S.R.H., Seidel, R., Masselter, T., Hartmeyer, I. \& Speck, T. (2012) Catapulting tentacles in a sticky carnivorous plant. PLOS ONE 7 (9): e45735.

https://doi.org/10.1371/journal.pone.0045735

Rivadavia, F., de Miranda, V.F.O., Hoogenstrijd, G., Pinheiro, F., Heubl, G. \& Fleischmann, A. (2012) Is Drosera meristocaulis a pygmy sundew? Evidence of a long-distance dispersal between Western Australia and northern South America. Annals of Botany 110: $11-21$. https://doi.org/10.1093/aob/mcs096

Rivadavia, F., Kondo, K., Kato, M. \& Hasebe, M. (2003) Phylogeny of the sundews, Drosera (Droseraceae), based on chloroplast $r b c L$ and nuclear 18S ribosomal DNA sequences. American Journal of Botany 90: 123-130. https://doi.org/10.3732/ajb.90.1.123

Robinson, A.S., Nunn, R., Bourke, G., McPherson S.R. \& Fleischmann, A. (2017) The genus Drosera. In: Lowrie, A., Nunn, R., Robinson, A.S., Bourke, G., McPherson, S.R. \& Fleischmann, A. (Eds.) Drosera of the World 1: Oceania. Redfern Natural History Productions, Dorset, pp. 2-110.

Saunders, D.A. (1989) Changes in the avifauna of a region, district and remnant as a result of fragmentation of native vegetation: the wheatbelt of Western Australia. A case study. Biological Conservation 50: 99-135. https://doi.org/10.1016/0006-3207(89)90007-4

Sheikh, S.A. \& Kondo, K. (1995) Differential staining with Orcein, Giemsa, CMA, and DAPI for comparative chromosome study of 12 species of Australian Drosera (Droseraceae). American Journal of Botany 82: 1278-1286. https://doi.org/10.1002/j.1537-2197.1995.tb12662.x

Sheikh, S.A., Kondo, K. \& Hoshi, Y. (1995) Study on diffused centromeric nature of Drosera chromosomes. Cytologia 60: 43-47. https://doi.org/10.1508/cytologia.60.43

Thiers, B. (2018) [continuously updated] Index herbariorum: A global directory of public herbaria and associated staff. New York Botanical Garden, Bronx, NY. Available from: http://sweetgum.nybg.org/ih/ (accessed 26 December 2017)

Western Australian Agriculture Authority (2014) The evolution of drought policy in Western Australia. Department of Agriculture and Food, Western Australia, 52 pp. Available from: https://agric.wa.gov.au/n/3316 (accessed 23 October 2017)

Welch, B.L. (1938) The significance of the difference between two means when the population variances are unequal. Biometrika 29 (3/4): $350-362$.

https://doi.org/10.1093/biomet/29.3-4.350

Worldbank.org (2017) Climate Change Knowledge Portal: Average Monthly Temperature and Rainfall for Australia from 1901-2015. Available from: https://perma.cc/9W96-FXN2 (accessed 23 October 2017)

Yesson, C. \& Culham, A. (2006) Phyloclimatic modeling: combining phylogenetics and bioclimatic modeling. Systematic Biology 55: 785-802.

https://doi.org/10.1080/1063515060081570 